\title{
THE PATH TO JIHAD:
}

\section{A CRITICAL METAPHOR ANALYSIS OF RELIGIOUS CONCEPTUALISATIONS IN JIHADIST MAGAZINES}

\author{
Name of author: Katie J. Patterson \\ Affiliation: Universidad de Granada \\ Email address: Kpatterson@ugr.es
}

\begin{abstract}
The ideological discourse of jihadist groups depends largely on their use of persuasive techniques as instruments for recruitment, radicalisation and more generally "to convince the audience of the veracity of the doctrine presented through it" [1]. The language choices of jihadists therefore play a crucial role in reflecting their social relationships, and their motivations and beliefs, as well as what attempts they make to justify or enforce these values.

By adopting Charteris-Black's [3] Critical Metaphor Analysis framework, this paper explores the use of metaphor as an important rhetorical and ideological dimension to jihadist texts. Data are taken from a collection of jihadist magazines which have been compared against the Qur'an. Results show that the pervasiveness of religiously inspired concepts like the JOURNEY metaphor help the writers to anchor their message to a deeply seated and authoritative set of ideologies. At the same time, semantic and pragmatic differences in the use of these metaphors suggest an ability to manipulate pre-existing conceptualisations to embody the principles of jihadist groups.
\end{abstract}

Keywords: Critical Metaphor Analysis; corpus linguistics; critical discourse analysis

\section{INTRODUCTION}

One of the key aims of both religious and politicallydriven writings is to influence the value systems of their readers. Thus, the credibility of a doctrine is closely linked to its ability to persuade. Aggarwal [2] claims that one way in which this is achieved is by deploying social representations to establish a shared culture through which individuals can interpret the world, or challenge mainstream ideologies. Analysis through a number of linguistic frameworks has revealed patterns in the linguistic choices of groups that unite political, social and cultural values [11]. For example, research has shown that authors of extremist material often "centre their rhetoric on themes of morality, social proof, inspiration and appeals to religion" [12]. Metaphoric language in particular, allows individuals to associate both social and experiential knowledge of world events together with their beliefs and values [7]. They can be used to invoke differences in power, social practices and principles. As a persuasive technique they can influence judgement, as well as elicit emotional responses that can sway moral evaluation [3]. This study focuses on the discursive aspects of religious metaphors in order to determine the extent to which jihadist writers depend on religion as a means to persuade. The research questions for this paper are the following:

- Are the same conceptual metaphors found in the Qur'an and jihadist magazines?

- To what extent are these metaphors used and/or adapted in the jihadist magazines?

- What do these religiously inspired metaphors contribute to the rhetoric of the jihadist magazines?

\section{CONTEXT}

\subsection{The rhetoric of terror}

Hegghammer [8] defines jihadism as a set of "cultural products and practices [that] serve as emotional persuasion tools that reinforce and complement the cognitive persuasion work done by doctrine". Groups like Al Qaeda and Islamic State found their ideologies on idealistic versions of Islam, making religion a key device in the creation and maintenance of the group's identity. Thus, aims are often defined in terms of providing a theological justification for group behaviour or actions, "drawing on well-established, mainstream religious concepts, in order to appeal to a vast ready-made, self-conscious constituency" [14].

Aggarwal [2] outlines three mechanisms of persuasion in Islamic extremist literature: "stipulating propositions for the audience to accept, invoking the authority of Quranic verses and scholars, and highlighting [the] audience's uniqueness". By doing so, such writers draw upon "shared linguistic practices to address an in-group defined through shared meanings of revering God" [2]. They are also able to exploit strong emotions such as "fear of retribution and obedience to God's path" [2] at the 
same time as identifying identity shared practices of jihad against 'other' groups.

\subsection{Metaphor and religion}

Jäkel [9] claims that texts will be largely dependent on metaphorical conceptualisation when dealing with topics that transcend our ordinary cognitive and sense experience. This is because of our need to ground something abstract into a concrete tangible experience. El-Sharif [5] makes the point that, in religion, metaphors are often the only way a writer can represent the unknown. Charteris-Black [3] claims that, by making something easier to understand, a writer is engaging in a joint activity of meaning creation; something that goes far beyond what is codified within the semantic system [3]. He cites this act of interpretation as reason for both the pervasiveness and effectiveness of metaphor within religious discourse.

Charteris-Black [3] demonstrates how the metaphor 'crusade of terror' used by George Bush after $9 / 11$ helped to strengthen a political ideology. The metaphor links the so-called war against terrorism directly to Islam through the association of religious crusades. Moreover, a metaphoric use of 'crusade' is shown to associate with negative collocates in the Bank of English, such as 'corruption', 'slavery', 'cancer' and 'crime' [3]. The research argues that the rhetoric used by Bush drew on the conceptual metaphor POLITICS IS RELIGION, whilst in contrast, the rhetoric of Osama Bin Laden (in ideological opposition) drew on the metaphor CONFLICT IS RELIGION. Both of these domains conceptualise terrorism in a way that furthers the agenda of each language user.

Findings from a study by El-Sharif [6] reveals how a deliberate choice of metaphor in the Qur'an can reflect a set of what he terms "key psychosocial dimensions" related to identity, appeals to authority, showing affiliation through ritual, a persistent conflict with evil, and the dichotomous relationship of an 'us' versus 'them'. El-Sharif [6] also gives the two metaphoric representations of God as "father" and "light" as examples invoking similar messages (portraying the existence of God as a necessity for humanity). Other conceptual metaphors portray God as a shepherd, a craftsman, a king or a judge [9].

\section{DATA AND METHOD}

\subsection{The corpora}

The corpus of jihadist magazines was created for a larger project entitled Nutcrackeri. In total there are
772 texts $(1,272,003$ words) taken from a number of complete issues of online magazines sourced from jihadology.net. These are Azan (published by the Taliban); Dabiq (Islamic State); Gaidi Mtaani (alShabaab); Inspire (al-Qaeda); Jihadi Recollections (al-Qaeda), and Rumiyah (Islamic State). The magazines are composed of a variety of texts including instructional guides, editorials and interviews, and have been coded for their source from the above journals (RV1-6), date of publication and their main function as shown below:

Table 1: Function code for each text in jihadist corpus

\begin{tabular}{ll} 
Code & Function/aim of text \\
\hline CP & Recruitment \\
AD & Indoctrination \\
IC & Incitation \\
FC & Financial support \\
IF & Instructional \\
PL & Planning a terrorist attack
\end{tabular}

The Qur'an will act as a comparator corpus. Metaphoric language is notoriously problematic to replicate in translations, specifically in religious writing [4]. For this reason, three different translations of the Qur'an are consulted, in order to attain a varied rather than an individual writer's style as well as a wide range of conceptualisations. The translations are freely available at Qurandatabase.org.

\subsection{Critical Metaphor Analysis}

Critical Metaphor Analysis can be defined as an approach combining Corpus Linguistics with Cognitive Linguistics and Critical Discourse Analysis. The model proposes three stages of analysis: identification, interpretation, and explanation, as proposed and outlined by CharterisBlack [3]. Identification involves discovering potential metaphoric keywords occurring both in the jihadist texts and the three Qur'an translations. Firstly, keyword lists were created to identify statistically significant lexical items in the Jihadist and Qur'an texts when compared to the BNC (acting as a general reference corpus). The next task was to see which of the items could be 'metaphor keywords', i.e. used in a metaphoric context. Charteris-Black's definition of metaphor keywords is "the presence of incongruity or semantic tension - either at linguistic, pragmatic or cognitive levels - resulting from a shift in domain use" [3]. Individual searches were 
undertaken of each listed item to determine which words had metaphoric potential.

The second stage (interpretation), involves a qualitative exploration of the context of concordance lines to determine individual instances of metaphoricity. The final stage (explanation) is concerned with textual meaning: in other words, how the metaphors function with reference to their specific situational context. In this paper, Wordsmith6 [13] has been used to identify collocation, patterns and cluster lists. The analysis involves identifying social agency as well as the rhetorical role of the metaphor. Pragmatic analysis such as Louw's [10] concept of semantic prosody is also relevant at this stage, in determining more subtle connotative differences within a given source/target domain. Key results from the analysis of only two conceptual domains are presented here: the JOURNEY metaphor and SPIRITUALITY AS NATURE.

\section{RESULTS}

\subsection{Domain 1: JOURNEY}

Out of the journey keywords identified, path is by far the most common item associated with this metaphor in both corpora. Moreover, with over 718 of the 729 instances of path being used metaphorically, this makes up $98.5 \%$ of all occurrences of path in the jihadist corpus. The majority of these metaphors refer directly to the path of Allah or the path of jihad. The path itself often describes the trials faced to arrive at the end goal of Allah's will:

(1) Thus, the group that fights, having traversed the path of waging jihad for Allah's cause, must grasp the nature of the battle, and what it demands for reaching its goal, that this path must be paved by the blood of its righteous RV6 AD 05042017

Here the path is not only covered with blood, but is created from it (paved), suggesting the inevitability or perhaps the necessity of sacrifice through violent acts in order to reach religious attainment.

The association of Jihad alongside Allah introduces a dialogic aspect to the texts, whereby the struggle (the translation of 'jihad') is as important as the arrival to Allah. Unsurprisingly for propagandist material, a large number of collocates (turn, follow, continue, proceed) are directive in nature. This also emphasises the notion of a journey which must be negotiated by the reader. Some collocates associated within this conceptual domain (e.g. true and clear) are not found in collocating positions with path in the translations, which suggests a rhetorical (hyperbolic) emphasis associated with the magazines. The war imagery in the jihadist corpus directly associated with path (fighting, assassination, enemy, tanks and killed) suggests a justification of such action for the jihadist cause. There is a sense that being killed can be a consequence of the journey; moreover, there is a positive pragmatic association in the larger textual environment, for example in the verb phrases associated with being killed (for example the desire to be killed or he wishes to be killed in the path of Allah).

In terms of colligational structures, the path is largely followed by the prepositional phrase of/to Allah or of/to jihad. These colligations have different associations. Path to/of jihad is used as a way towards Allah (for Allah's cause; until they achieve), but it is less frequently used than the path of Allah, suggesting jihadism as a means to Allah. There is often a sense of negative semantic prosody with the path of Allah (difficulties, high price, obstacles), emphasising that the choice to become a jihadist is not an easy one. In this case, the use of semantic prosody adds an attitudinal layer of meaning that is not present in the Qur'an. This is a technique that helps the writers in their aims of recruitment and incitement.

The majority of collocates in the jihadist corpus are not present alongside path in the Qur'an corpora, which suggests that these are seemingly religious goals but attained only through modern day jihadism. In the translations, there are only two references to the path to (one is misery, the other is bliss). In the Qur'an, the most frequent collocate is from in R1 position, together with a range of items which create a sense of negative prosody associated with the colligation (astray, obstructed, misguided and hinder). Thus, path is not used as a persuasive strategy (path to) but rather as a deterrent (do not divert from the path).

\subsection{Domain 2: SPIRITUALITY IS NATURE}

It seems obvious for this domain to provide the basis for the conceptualisation of religion (spiritual) as something inherently good (natural). One way in which this is frequently conceptualised is through the notion of growth. The item seed is revealed to be key in both corpora. In the Qur'an, recurrent conceptualisations of creation (e.g. Of what thing did He create him? "Of a small seed") account for the majority of instances of the item. Collocates of seed are largely semantically associated with nature (grain, mustard, stone, twine, clot), even though these instances relate to the creation of man by Allah.

We also see this in the jihadist corpus, but the metaphor is extended to represent growth towards the jihadist cause. This is a manipulation of the metaphor, 
showing how persuasion manifests in the jihadist literature, as in this text with the aim of recruitment:

(2) $[. .$.$] pieces of my body which I scatter like$ severed limbs in the ether, for their echoes to reverberate in your ears forever, and for me to plant them like seeds in your consciences, in the hope that out of them will grow jihad if I water them with my blood tomorrow RV4_CP_000910

What we also see is that the metaphor has developed from a largely concrete transference in the Qur'an (the seed as physical creation) to abstract in the magazines; the most frequent noun collocates of seed* are largely abstract (faith, doubt, kufr, and Islam). In an example with kufr (The war of kufr on Islam and its seed, resulted in battalions uprooting Crusader weeds RV_AD_000911), the connotations are negative: the seed of kufr has the potential to sabotage the crusaders' work. The purpose is to destroy kufr in its earliest manifestations in order for the crusaders to succeed. Interestingly, crusader weeds overturns the negative prosody associated with weeds more generally. The extended metaphor signifies the crusaders as hardy and growing in the face of resistance.

There is also evidence in the jihadist magazines of the metaphor being transferred to new concrete domains, further removed from the original source domain of creation and physical growth. The example below shows money depicted as seeds in this extended allegories:

(3) He [Allah] compares the money spent in His path to a seed. This seed grows into seven different spikes, each of the spikes containing a hundred grains [...] A hundred grains on seven spikes, this would mean 700 grains. From these 700 grains could sprout 700 hundred more plants RV5_FC_000509_001

This use of seed is far removed from the initial creation and spirituality association, suggesting another development of the metaphor; perhaps we can go so far as to suggest giving money is closer to showing faith to the cause or even some form of spiritual attainment. This is unsurprising as the text has been labelled as 'financial' in its aim.

Another keyword in the domain of spirituality is 'forth' which is used in the Qur'an to symbolize life, and with it, spiritual oneness with Allah. Phrases such as bring forth and flow forth show this conceptualisation. Here we again bear witness to the idea that faith in Allah is something natural, and that
Allah will provide food and water to those willing to believe. In the jihadist corpus, the same metaphor is used to promise a restoration to the natural state of abundance. This acts as a tool of persuasion, promising readers that submission to the cause will provide future rewards:

(4) That the Khilafah will be established on earth once more. The earth will become free of Fasaad once more. It will pour forth its growth yet again. Happiness would spread! The weak would be given justice! RV_CP_000613

However, we also see a manipulation of this religious imagery for the aims of the jihadist cause:

(5) He remained steadfast in the face of everything he was afflicted with, never weakening, never surrendering, until Allah gave him triumph and his blood was spilled, pouring forth and fuelling the lantern that illuminates this noble path RV6_CP_05092016.

The quote refers to a "chivalrous muhajir" and seeks to justify his acts of killing. Here, the blood is depicted as the life force rather than water. In this way, blood is the provider, or life, and without the killings, life cannot flourish. There are also instances of "firepower and bombs", "arrows of defamation and tongue-lashing" and "tears" pouring forth. These all display a negative prosody used to justify immoral acts in the context of the jihadist cause.

\section{CONCLUSIONS}

Whilst it is shown in this snapshot of the analysis that the jihadist texts use the same metaphors as the Qur'an to place their ideology close to that of Islam, the jihadist writers' also diverge in their uses of these metaphors. What they are able to do through these creative manipulations of characteristically religious metaphors, is to draw on the association with the Holy book to instil their own aims and, at times, justify certain acts. It is undeniable that readers of the jihadist magazines will be familiar with the metaphoric domains prevalent in the Qur'an. To conclude, the paper has shown how critical metaphor analysis can identify ideological differences in texts, and how these differences can act as a tool to persuade. 


\section{ACKNOWLEDGMENTS}

This research forms part of the project ISCID and has received funding from the European Commission H2020 MSCA-IF-2019-ID:882556

\section{REFERENCES}

[1] Adam, M., 2017. Persuasion in religious discourse: Enhancing credibility in sermon titles and openings. Discourse and Interaction, 10(2): 525.

[2] Aggarwal, N.K., 2019. Media Persuasion in the Islamic State. Columbia University Press.

[3] Charteris-Black, J., 2004. Corpus approaches to critical metaphor analysis. Springer.

[4] Dweik, B.S., Shakra, M.M.A., 2010. Strategies in Translating Collocations in Religious Texts from Arabic into English. Atlas Global Journal for Studies and Research, Online Submission. Available https://files.eric.ed.gov/fulltext/ED510365.pdf

[5] El-Sharif, A., 2011. A linguistic study of Islamic religious discourse: conceptual metaphors in the prophetic tradition (Doctoral dissertation). Available at: https:/qmro.qmul.ac.uk/xmlui/bitstream/handle/1 23456789/2417/EISHARIFLinguisticStudy2011. pdf? sequence $=1$

[6] El-Sharif, A., 2016. A Theoretical Account on the Study of Metaphor in Didactic Discourse. Advances in Language and Literary Studies, 7(2), 100-112.

${ }^{\mathrm{i}}$ Created by Miguel-Ángel Benítez-Castro (University of Zaragoza), Azzam Dhiab Hassan and Encarnación Hidalgo-Tenorio (University of Granada) in the framework of the Research Project "Nutcracker: Sistema
[7] Fairclough, N., 1992. Discourse and text: Linguistic and intertextual analysis within discourse analysis. Discourse \& society, 3(2),193217.

[8] Hegghammer, T. (ed)., 2017. Jihadi culture. Cambridge University Press.

[9] Jäkel, O., 2002. Hypotheses revisited: The cognitive theory of metaphor applied to religious texts. Metaphorik.de, 2(1): 20-42.

[10] Louw, B., 1993. Irony in the text or insincerity in the writer? The diagnostic potential of semantic prosodies. Text and technology: In honour of John Sinclair, 157-176.

[11] O'Regan, J.P., Betzel, A., 2016. 19 Critical Discourse Analysis: A Sample Study of Extremism. Research Methods in Intercultural Communication, p.281.

[12] Prentice, S., Rayson, P., Taylor, P.J., 2012. The language of Islamic extremism: Towards an automated identification of beliefs, motivations and justifications. International Journal of Corpus Linguistics, 17(2), 259-286.

[13] Scott, M., 2011. WordSmith Tools Manual, Version 6. Liverpool: Lexical Analysis Software Ltd.

[14] Sedgwick, Mark 2004, Against the Modern World: Traditionalism and the Secret Intellectual History of the Twentieth Century, Oxford University Press.

de detección, rastreo, monitorización y análisis del discurso terrorista en la red" (reference number FFI201679748-R) funded by the Spanish Ministry of Economy and Competitiveness. 